Studia Anglica Posnaniensia 51/3, 2016

doi: 10.1515/stap-2016-0015

\title{
BUSZEL, KOMBAJNER, AND RELS: \\ FISIAK'S 1961 CORPUS OF ENGLISH BORROWINGS IN POLISH FIFTY FIVE YEARS LATER
}

\author{
RADOSŁAW DYLEWSKI*
}

Faculty of English, Adam Mickiewicz University in Poznań

\begin{abstract}
The onset of Professor Jacek Fisiak's scholarly career is marked by his $1961 \mathrm{Ph} . \mathrm{D}$. dissertation devoted to the lexical influence of English upon Polish. This study, conducted 55 years ago, offers a multilayered analysis and sets the standards of studies on lexical transfer from English to Polish for the years to come. The present article is a tribute to Fisiak's first scholarly endeavor; it examines the fate of lexical items comprising Fisiak's corpus in the second decade of the $21^{\text {st }}$ century. More specifically, by conducting searches in the National Corpus of Polish as well as a Google search, the paper checks which borrowings to the Polish language listed and scrutinized by Fisiak gained popularity, which fell out of use, and which underwent semantic changes.

Keywords: borrowings, calques, English borrowings in Polish, semantic change, lexical change

\section{Introduction}

Professor Jacek Fisiak's is a renowned scholar who received his world-wide recognition mainly thanks to his outstanding and oftentimes pioneering works on English historical linguistics. Very few might be aware of the fact, however, that he started his scholarly career with a Ph.D. dissertation devoted to what he calls "lexical interference" and which deals with the lexical influence of English upon Polish (Fisiak 1961a). His dissertation, to my knowledge, was the first booklength treatment of the subject carried out in a systematic manner and whose author scrutinized a number of pertinent aspects: not only did Fisiak focus on the
\end{abstract}

Faculty of English, Adam Mickiewicz University, al. Niepodległości 4, 61-874 Poznań, Poland, e-mail: dradek@wa.amu.edu.pl. 
typology of borrowings, their directness/indirectness, semantics, and grammatical category/ies they fall in, but also on various phonetic changes which affected borrowed items once they started to be used in the Polish language. The latter aspect of Fisiak's study deserves special appreciation since he showed here remarkable meticulousness and the phonetic analysis with all its subtleties and intricacies was done in the times devoid of present-day devices and computer programs which ostensibly make life of a phonetician much easier.

Apart from all these, the dissertation gives the reader information concerning the process of transfer of English word stock into Polish prior to the creation of the dissertation; even though from the $21^{\text {st }}$-century perspective the influence of English on Polish seems a relatively new phenomenon, already in 1961 Fisiak claimed that it had been a 170-year-long process which took place in the following three stages:

Stage I: Since the end of the $18^{\text {th }}$ century until roughly 1850 ;

Stage II: Circa 1850 till circa 1900;

Stage III: Since 1900 until 1961.

The border between Stages I and II is delineated by the publication of Linde's (1850) dictionary; similarly, the staring point for another dictionary - this time Karłowicz et al.'s (1900-1927) ${ }^{1}$ - marks the border between Stages II and II; these two works, according to Fisiak, ought to be regarded as milestones in treatment of the historical development of Polish lexicon between 1850 and 1960s.

When it comes to lexical items per se, Fisiak points out that in these three respective stages the character of borrowed items differed markedly. Thus, Stage I can be characterized by borrowings mainly via French (for example, kontredans) and German; these were preponderantly, as Fisiak calls them, "graphical borrowings". Stage II is marked by items which were transplanted to Polish mainly through the German language; these were mainly graphical borrowings, nonetheless, importantly, the first direct ones started to make their way into Polish. It is during this stage when numerous items from the following semantic fields were borrowed: industry, trade, maritime industry, trade union movement, science, and sport. Finally, Stage III is characterized by a large number of direct borrowings encompassing a variety of aspects of life as well as numerous items from the realm of sports.

Fisiak's corpus consisted of 721 borrowings gathered from an array of dictionaries - all listed in the bibliography of the present paper $^{2}-$ as well as

The dictionary is actually an outcome of a collective effort by Karłowicz, Kryński \& Niedźwiedzki (1900-1927).

2 For instance, Rysiewicz (1954), Skibicki (1951) or Wieczorkiewicz (1939). 
daily press sports magazines embracing the time span of three years: 19581961. ${ }^{3}$ Unsurprisingly, knowing that nouns are transferred from one language to another most easily, out of this number 681 items were identified as nouns (where 598 were masculine, 52 - feminine, 18 - neuter, and 13 of undetermined gender). The rest were verbs and adjectives.

For the purpose of the present study, however, 684 borrowings were subject to linguistic analysis. The actual discrepancy between the number of lexical items borrowed to Polish given by Fisiak (1961a) and the number analyzed in the present paper, even though the index to Fisiak's dissertation was scrutinized in its entirety, stems from the fact that the former treated spelling variants as separate entries, whereas here orthographic variants are lumped together into one entry.

Summing up the introductory part to the paper, the following has to be emphasized: the dissertation under discussion here is dated 1961; it was thus written in the times of neither personal computers nor the Internet, with access to information limited to hard copies of printed matter. These were the times, needless to say, when scholarly publications were typewritten and, if need be, corrected manually. Having taken all these into consideration, Fisiak's piecemeal approach to the issue, his multilayered and versatile approach, and the work per se deserve even more appreciation. The present study which analyzes Fisiak's corpus 55 years later is a tribute to Professor Fisiak's pioneering work.

\section{Methodology and research questions}

In order to observe the present-day status of borrowings listed by Fisiak (1961a), the following methodology was adopted: first, all items drawn from index to the dissertation were transferred manually to an Excel file. Additionally, the whole dissertation was scrutinized in search of entries which had not made their way into the said index. Then, all of the culled borrowings were checked in the National Corpus of Polish ${ }^{4}$ (NCP); if they were not recorded in this source or, as in the case of bufor (in Fisiak: rubber base between a spring and body of the car), the number of attestations was far too large as to allow for pinpointing the appropriate meaning subtlety, a Google search (described below) was conducted. Preference was given to on-line dictionaries and, in the case of jargon terms, to specialized websites. The returned results, with necessary caution in mind, are used later on critically and carefully.

3 The choice of sports magazines is by no means accidental and it seems to have stemmed from extralinguistic rather than linguistic choices. Professor Fisiak is an ardent sports fan, hence the interest in sports press of the time.

4 http://www.nkjp.uni.lodz.pl. The search engine used here is Pęzik's (2012). 
The Google search was customized by the use of advanced search features in such a way as to limit the retrieved results to the ones (a) appearing only in the Polish language and (b) covering the time span of the last sixteen years (20002016). If applicable and needed, especially with the borrowings which exhibit multiple semantics nowadays, supplementary keywords were used to yield particular meaning(s) of a word sought from the Google search engine.

The latter policy needs a word of clarification. E.g., the lexeme master exists in Fisiak (1961a: 114) as "kierownik biegu myśliwskiego" (Engl.: "a leader of a hunting race"). Eliciting such a meaning out of literally thousands of returned results $^{5}$ of various sorts is a next-to-impossible task. Thus, key word combinations, including Boolean strings as well as additional key words/phrases were utilized.

Having carried out the search, all gathered entries were tagged appropriately for the following categories: common vs. less common/rare/absent, meaning change (extension, narrowing, and shift respectively), spelling change, technical terminology/jargon ${ }^{6}$ and, finally, their being obsolescent (phenomena) nowadays. It must be stated that the process of distinguishing particular categories was done arbitrarily which makes them indiscrete; such a division, nonetheless, is assumed to suffice since the aim behind the present paper is to indicate certain trends and changes that affected groups of items, rather than individual ones, dealt with by Fisiak (1961a) within the last 55 years.

Needless to say, a close scrutiny of all individual words would take a booklength format. In a nutshell, the major aim is to check which borrowings to Polish became more popular, which dropped out, and which underwent meaning alterations. This is done in the sections to follow.

\section{Discussion}

\subsection{Vocabulary items which gained popularity in Polish}

Out of 684 lexical items drawn from Fisiak's corpus, as many as 355 (approximately 52\%) got very closely interwoven into the linguistic fabric of Polish (cf. Figure 1), and many of them have been assimilated to such an extent that nowadays Poles might be hardly, if at all, aware of their foreign provenance.

5 Master is an oft-selected lexeme for the sake of brand- or company/business-naming. The Google search yielded a plethora of results of the kind; to list but a few: Foto-Master, Lex Master, Master-Serwis, Wood Master, Master Gust, Grotop Master, Master-Jang, Master Moving, and Master-Bus.

6 When applicable, of course. 
Figure 1. The ratio of "common" to "less-common/rare" items in Fisiak's (1961a) corpus.

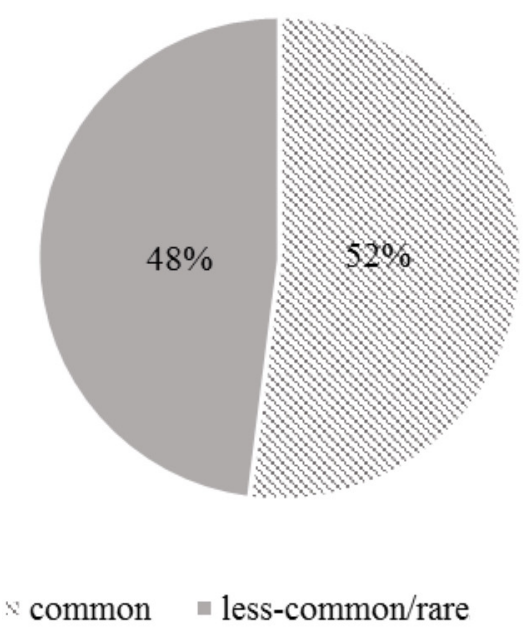

For instance, borrowings such as autokar ${ }^{7}$ (Engl.: coach), dres (Engl.: tracksuit), hol (Engl.: hall), jacht (Engl.: yacht), klan (Engl.: clan), radar, spaniel, sport, rekord (Engl.: record), runda (Engl.: round), partner, and wigwam have been used extensively in the Polish language for decades. Interestingly, the usage of certain borrowings in Polish coincides with their use or their one-time popularity in English. An illustrative example is pin-up girl, a phenomenon and a phrase which at present witness revival on both sides of the Atlantic. Pin-up girl was used in Polish in the 1950s, which was noted by Fisiak (1961a). Intriguingly, the search using the key-phrase pin-up girl in the Corpus of Historical American English $(\mathrm{COHA})^{8}$ allowed for the retrieval of the following results presented in Figure 2 (see next page).

Indeed, its use in American English starts during the Second World War and its peak does overlap with the presence of pin-up girl in Polish of the twentieth century; more specifically it is the 1950s, the decade at the end of which Fisiak collected English borrowings in the Polish language.

\footnotetext{
7 The word is derived from a combinations of two English elements: auto- and car.

8 Date of access: 20.06.2016.
} 
Figure 2. Diachronic distribution of pin-up girl in the Corpus of Historical American English.

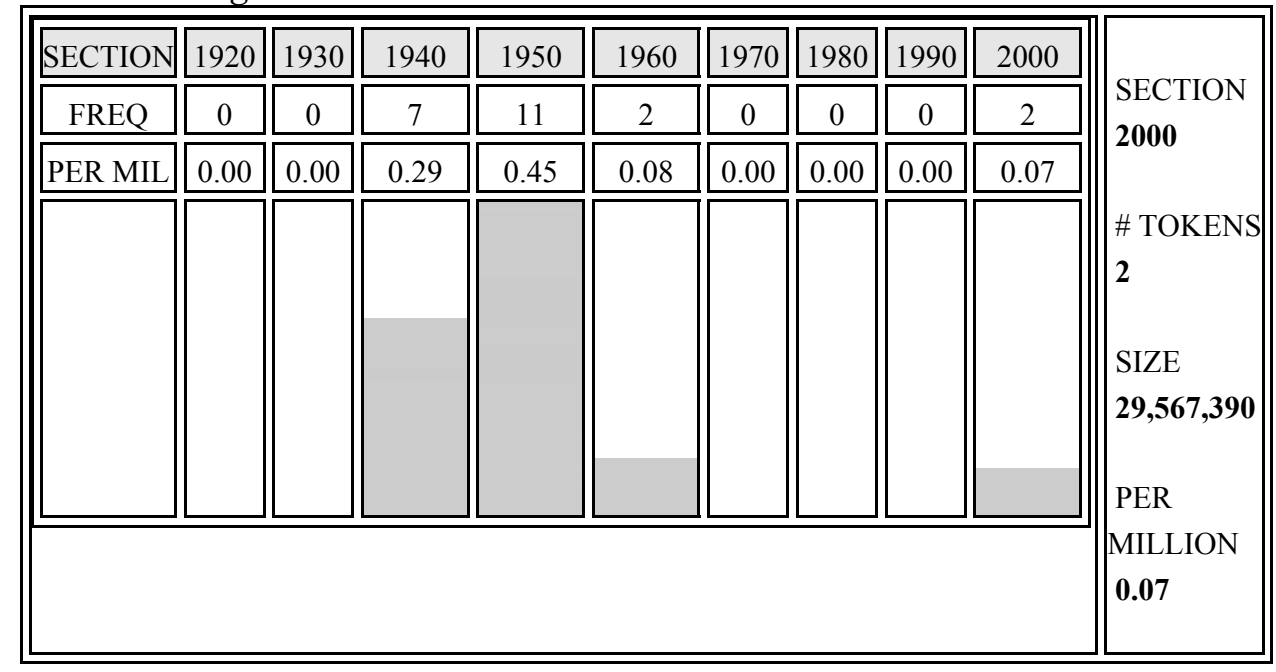

Coming back to the category which groups the so-called "common" borrowings, due to their immense popularity in Polish, their semantic analysis, study of meaning or functional changes, etc., constitute topics in their own right and are beyond the scope of the present paper. The short discussion below, however, exemplifies certain trends which can be observed among borrowings belonging to this group. ${ }^{9}$

Let us focus on the items which witness popularity in present-day Polish and which have undergone the following three types of changes: (a) the change of the phenomenon as such (which finds its description below), (b) semantic change (it is usually broadening of the meaning which affected a borrowed word), and (c) the change in spelling.

When it comes to the first one, there is one exemplary case which falls into the category of phenomenon change. Fisiak (1961a: 112) gives the following definition of the term dres (Engl.: tracksuit): "sweatshirt and pants made of wool or flannel". Obviously, the $21^{\text {st }}$ century tracksuits are usually made of polyester, nylon, cotton or various combinations of these types of material. Accordingly, Fisiak's meaning has undoubtedly fallen into obsolescence due to the change of production technology and the fabric(s) used to produce tracksuits.

9 As indicated above, an analysis of such words as rekord (Engl.: record), runda (Engl.: round), szeryf (Engl.: sheriff) or western (Engl: the Western) from the angle of functional change on an individual basis would fill in a book-length space. 
Some of the popular items have undergone the meaning extension process, for example cross, drajw, net, or singel. Next to the respective meanings given by Fisiak, over the years new semantic layers have been added: thus, cross (in Fisiak: "to hit the tennis ball from one corner of the tennis court to the opposite one") also functions as a noun and means "running across ...". Additionally, the word has conformed to Polish morphology and functions as a verb krosować (to cross) and as a gerundial form (s)krosowanie (cross-connection). Recently, it also has been re-borrowed as the name of fitness regimen crossfit.

The extended meaning of drajw, next to the one noted by Fisiak (1961a, 1970), is exemplified by quotes 2 and 3 :

1. Zamaszysty - zauważył sędzia - Jak drajw z forhendu. ${ }^{10}$

[English]: Dashing - noted by the referee - just like a forehand drive.

2. otwiorzcie program i WSKAZCIE na ten drajw (litera dysku) w ktorym jest plyta. ${ }^{11}$

[English]: open the program and indicate the drive (drive letter) in which there is a CD.

3. Gudrun nazywa Andreasa Bejbi, on ją natomiast - Kotką. Ale to ona ma drajw, a nie on - zazdrosny, niedouczony, brutalny maminsynek. ${ }^{12}$

[English]: Gudrun calls Andreas "Babe" and he calls her - "Kitty". But it is her who has the "drive", not him - he is a jealous, ignorant, brutal sissy.

Net is in Fisiak (1961a) used only in the context of tennis, as a shot that must be replayed. Next to this usage net is currently used colloquially as a term tantamount to the World Wide Web. In a similar vein to the previous borrowing, net did succumb to Polish morphology and can be found, inter alia, in: "tego nie ma na necie" (Engl.: "this is not on the net") or in a diminutive form "necik śmiga" (Engl.: "the Internet is working just fine").

Singel (also singiel), given in Fisiak in the tennis context as well, acquired the following meanings of "a vinyl record with one track on each side", "a song selected to promote an album", "the only card of a given color given during dealing", and, most importantly, "a person without a partner living alone". ${ }^{13}$

Finally, some of the items are used nowadays in a different orthographic form from the one provided in the dissertation, or speakers of Polish have two (or more) variants at hand. For instance, Fisiak lists only the assimilated

10 The National Corpus of Polish. Józef Hen. 2008. Pingpongista. Wydawnictwo W.A.B.

11 Original spelling retained. The National Corpus of Polish. Usenet. Date of publication: 18.11.2003. Authors: "rympal", "Panslavista", "KooL THING.....".

12 The National Corpus of Polish. Adam Krzemiński. 2008. Polityka 2675.

13 These are the dominant meanings. For more, see: https://pl.wikipedia.org/wiki/Singel. 
orthography of coca cola: koka-kola, the preponderant spelling of which nowadays is the former, possibly due to an increased exposure of Poles to commercials advertising this brewage and the brewage as such. By the same token, Fisiak mentions only sandwicz, which also exists in present-day Polish in its original, English spelling form - sandwich. A reversed trend is observable in the case of grape-fruit, trick, yacht-club, and yard, all of which are currently (also) in use in their assimilated orthography; respectively: grejpfrut, trik, jacht $k l u b$, and jard.

\subsection{Less-common/rare items}

Far more rewarding is the next category which comprises almost half of the cases found in Fisiak's index. As for ways of classification, a given word was categorized as "less-frequent/rare" if it had not been found in the National Corpus of Polish or it had been recorded there, but either as a Wikipedia entry or (solely) in a source published originally prior to $1990 .{ }^{14}$

The reason why items belonging here do not enjoy popularity nowadays is that for the most part these can be thought of as jargon terms (next to the other entries which anyway have fallen out of use as time went by); some of them seem to have been rare over fifty years ago and they still are, their usage being confined to specific or (very) narrow contexts.

More specifically, a certain proportion of items constituting the present category can be still found in dictionaries of Polish, dictionaries of foreign words in Polish, (fairly) specialized Internet forums, proper (or brand) names, scrabble word finders, and hints for crossword puzzle lovers. To exemplify this, dolly, according to Fisiak (1961a), is a tripod or platform for a motion-picture camera. It can be found amongst Polish texts on the Internet as, inter alia, "stabilizator typu Dolly" ("Dolly-type stabilizer") ${ }^{15}$ or "jak zrobić solidną jazdę kamerową (wózek dolly) ("how to make a tough camera platform (dollywheeled platform)"). Next, rober, which in Fisiak (1961a: 116) means "one of the stages of contract bridge game", alongside its diminutive form roberek, are to be found in scrabble cheats, bridge-lover sites, and crossword puzzle solutions.

All in all, due to the relative rarity of loanwords falling into the present category, their more thorough analysis - at least in comparison to the previous category - seems more feasible. In the sub-sections to follow, particular entries

\footnotetext{
14 The corpus also comprises Wikipedia articles in Polish as well as publications from the first half of the $20^{\text {th }}$ century.

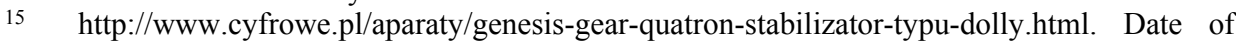
access: 20.05.2016.
} 
are discussed in accordance with the categories/sections they belong to. These categories/sections are: (1) semantic change (meaning extension, narrowing, and shift); (2) spelling change; (3) technical/jargon terms, and (4) obsolescent terms/phenomena nowadays.

\subsubsection{Semantic change}

Fisiak (1970: 41) claims that "the semantic adaptation of loanwords in the borrowing language ... also affects the internal structure of such an entry modifying its paths by the addition or deletion of a semantic marker, distinguisher or restriction. This leads to the phenomena traditionally known under the headings of the narrowing, extension and shift of meaning". In the corpus consisting of 329 less-frequent/rare borrowings from English into Polish, 65 items $(19.76 \%)$ have been identified as those which nowadays appear with a different meaning, out of which 62 have extended (broadened) their meaning, 2 have undergone narrowing of meaning, and only 1 has experienced meaning shift. Table 1 depicts meaning changes across the established semantic categories; Figure 3 illustrates the numerical data for the borrowings which underwent semantic changes and for the ones which remained unaffected:

Table 1. Meaning changes affecting semantic categories (less-frequent/rare lexical items). ${ }^{16}$

\begin{tabular}{lccccc}
\hline category: & extension & narrowing & shift & no change & total: \\
\hline $\begin{array}{l}\text { alloys/metallurgy/ } \\
\text { mining }\end{array}$ & 1 & 0 & 0 & 11 & 12 \\
$\begin{array}{l}\text { animal } \\
\text { breeds/breeding }\end{array}$ & 1 & 0 & 0 & 3 & 4 \\
$\begin{array}{l}\text { automobile } \\
\text { (industry) }\end{array}$ & 1 & 0 & 0 & 2 & 3 \\
aviation & 1 & 0 & 0 & 1 & 2 \\
biology & 0 & 0 & 0 & 3 & 3 \\
botany & 1 & 0 & 0 & 3 & 4 \\
chemistry/physics & 1 & 0 & 0 & 4 & 5 \\
cinematography & 3 & 0 & 0 & 11 & 14 \\
clothing & 4 & 0 & 0 & 4 & 8 \\
dendrology & 0 & 0 & 0 & 1 & 1 \\
dying substances & 0 & 0 & 0 & 1 & 1 \\
economy/pecuniary & 4 & 0 & 1 & 7 & 12 \\
terms & & & & &
\end{tabular}

16 Respective categories as well as illustrative examples are presented in Appendix 1. 
R. Dylewski

\begin{tabular}{lrrrrr} 
electricity (circuits) & 2 & 0 & 0 & 3 & 5 \\
equine $^{17}$ & 0 & 0 & 0 & 1 & 1 \\
fabric & 1 & 0 & 0 & 12 & 13 \\
geology/geography & 1 & 0 & 0 & 6 & 7 \\
historic architecture & 0 & 0 & 0 & 1 & 1 \\
(obsolete) political & 1 & 0 & 0 & 21 & 22 \\
terms & & & & & \\
hunting & 2 & 0 & 0 & 0 & 2 \\
legal issues & 0 & 0 & 0 & 2 & 2 \\
literature & 0 & 0 & 0 & 2 & 2 \\
machinery & 2 & 0 & 0 & 10 & 12 \\
maritime & 0 & 0 & 0 & 4 & 4 \\
architecture/ & & & & & \\
technology & & & & & \\
measures and & 0 & 0 & 0 & 2 & 2 \\
weights & & & & & \\
medicine & 0 & 0 & 0 & 2 & 2 \\
military/weaponry & 0 & 0 & 0 & 8 & 8 \\
music (styles) & 0 & 0 & 0 & 3 & 3 \\
railway & 3 & 0 & 0 & 7 & 10 \\
(technology) & & & & & \\
sailing/shipping & 13 & 0 & 0 & 35 & 48 \\
sport & 11 & 0 & 0 & 33 & 44 \\
substances & 0 & 0 & 0 & 1 & 1 \\
technology & 0 & 0 & 0 & 8 & 8 \\
vehicles & 1 & 0 & 0 & 3 & 4 \\
other & 9 & 1 & 1 & 48 & 59 \\
\hline Total: & $63 / 329$ & $1 / 329$ & $2 / 329$ & $263 / 329$ & $329 / 329$ \\
\hline
\end{tabular}

As for the extension (broadening) process, due to its being seemingly the most productive one, it is subject to description first; nonetheless, because of space limitations, it is not dealt with on an individual basis and only a few illustrative examples are provided below. ${ }^{18}$

17 Fisiak (1970: 44) classifies it (tatersal; Engl.: Tattersall = "the horse-auction market"; "equestrian facility") as not belonging to the category of equestrian events, but he puts it amongst trade terms.

18 The same policy is adopted in the case of the remaining categories. 
Figure 3. Semantic change affecting the less common/rare borrowings.

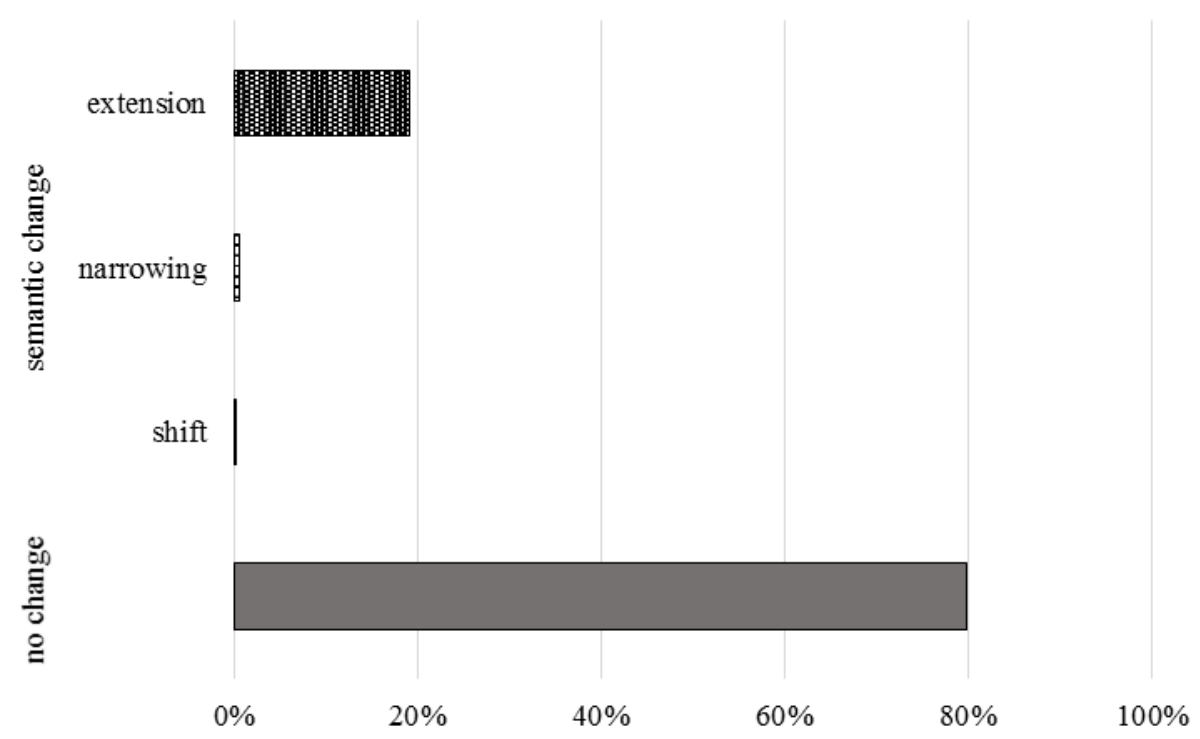

The question arises why relatively few items (less than 20\%) have undergone meaning changes. The answer seems rather straightforward and has been indirectly answered at the beginning of this section - many of the words which constitute the collection of less-common items of English origin in Polish are specialized (jargon) terms (82\%) or the obsolescent ones (or both). Accordingly, because of their usage in (relatively) narrow contexts and general unpopularity, they did not succumb to the types of semantic change discussed thus far.

\subsubsection{Words with extended meaning}

At first glance, surprisingly, it is the marine terms ${ }^{19}$ (sailing/shipping category in Table 1) which lead the way when it comes to meaning extension. However, this unexpected semantic broadening of (rather) rare lexical items can be explained on the following grounds: such items as (a) lajner (Engl.: liner), (b) lider (Engl.: leader), (c) log, (d) sprej (Engl.: spray), (e) trymowanie (Engl.: trimming), which in Fisiak (1961a, 1970) exist in the following respective meanings: (a) "an athlete occupying last position/passenger ship", (b) "flotilla leader", (c) "a device to

19 The abundance of borrowings belonging to this particular semantic category stems from Fisiak' relying on Brocki \& Hołowiński (1956), Skibicki (1951), Śląski (1937), and Stowniczek morski. 
record the ship navigation", (d) "drops of water instigated by marine breeze", and (e) "the process of distributing weights to assure maximum ship stability" did not in fact acquire new meanings in the course of the last 55 years. As a matter of fact, during that time-span they have been re-borrowed into Polish, but in the new denotations which eventually pushed the original/older meanings aside; thus, lajner (it also exists in its original, English orthography: liner) enter Polish in the collocation eye liner and such a usage can be encountered frequently on the Polish web; ${ }^{20}$ lider (also: leader) is very rarely used in the meaning of a leading ship, since lider (leader) was borrowed to Polish later on as a person who leads other people, groups of people, has authority to tell people what to do, etc. Needless to say, the latter denotation is by far the prevailing one. Next, with the accessibility and popularity of the (personal) computer, $\log$ - which usually appears in a pluralized form logi (Engl.: $\log s)$ - has come to be a common term in the jargon of computer usage/programing. The word conformed to Polish orthographic and morphological conventions, giving rise to logowanie (Engl.: logging), za/wy/logować (Engl.: to log in/out). As for sprej (alongside its orthographic variants - spray and spraj), it is hardly ever used in the context of drops of water raised by sea wind; rather, it can denote isotonic solution, but it generally means a device used to spray a liquid with (Engl.: sprayer). Finally, trymowanie (Engl.: trimming as well as a verb - trymować; Engl.: to trim) in contemporary Polish refers more to trimming (canine) hair or trimming sails than to an even distribution of weights on a ship.

Likewise, however to a more limited extent, the word tramp (Fisiak's denotation: "a cargo ship which does not cruise regularly") is currently used in a signification different from Fisiak's (1961a, 1970). Interestingly, Cambridge Dictionary Online ${ }^{21}$ does not provide such a definition of the word - the only one given is "someone who has no home, job, or money and who lives outside" (s. v. tramp); that is exactly the meaning attested in contemporary Polish. It is the Oxford English Dictionary which provides the reader with the following: "a cargo vessel, esp. a steamship, which does not trade regularly between fixed ports, but takes cargoes wherever obtainable and for any port" (s. v. tramp, n.).

When it comes to the terms dubbed broadly as sports terms, where out of 44 entries 11 cases $(25 \%)$ underwent meaning extension, the following entries illustrate the phenomenon. Skrecz (Eng.: scratch; in Fisiak (1961a: 114): "withdrawal from a tennis tournament; giving up") nowadays signifies mainly the sound produced by a DJ while spinning records during a show. Earlier, before skrecz entered Polish lexicon in the modern meaning, a sports term -

20 Liner has again been transplanted to Polish in the aircraft term dreamliner, which was subjected to the rules of Polish morphology.

21 http://dictionary.cambridge.org. Date of access: 24.07.2016. 
$k r e c z$ - had been derived thanks to the mechanism of folk etymology (see the end of section 3.2.2.).

Next, Fisiak (1961a) lists autsajder amongst sports terms and describes it in the context of the last participant of a race/competition. In a similar vein to the previous examples, the newer meaning - in this particular case of "the person not accepted by a given group or a society or the one who voluntarily isolates from their environs" - marginalized the denotation provided by Fisiak. Interestingly, as far as spelling is concerned, one of the Polish prescriptivists, prof. Bańko, states that the one-time attempt at orthographic assimilation of outsider and giving it the form of autsajder did not withstand the test of time. ${ }^{22}$

As for other terms, master, according to Fisiak, meant a "kierownik biegu myśliwskiego" (Engl.: "leader, organizer of a hunting race"); this denotation is by all means rare and it hardly ever occurs, but for very specific (professional) contexts. Nowadays master can also be used, for instance, in computer jargon while discussing relations between two connected electronic devices (where one of these is the superior one, called master, and the other - slave).${ }^{23}$ Additionally, this borrowing might be applied in other technical uses: "an original (of a sound recording, film, data file, etc.) from which copies may be made" (the $O E D$, s.v. master, $\mathrm{n}$.).

Furthermore, in Fisiak (1961a) squatter is "a settler having no formal or legal title to the land occupied by him, esp. one thus occupying land in a district not yet surveyed or apportioned by the government" (the OED, s. v. squatter, n.). With the advent of squatting in Poland, this primary meaning has ostensibly given way to the new one which rapidly gained ground: "one who occupies an uninhabited building illegally (esp. as a member of an organized group)" (the $O E D$ s. v. squatter, n.). The older sense of a settler appears sporadically, whereas sktoter living in a squat (or sklot) is the predominant one.

\subsubsection{Narrowing of the meaning}

As has been mentioned earlier, only one word from Fisiak's corpus has been identified as having undergone this process: this one is Mohikanin/nie. Mohikanin (Engl.: the Mohican), explained in Fisiak (1961a) as "the last member of a given group, etc." exists in Polish in reference to an Amerindian tribe. Currently, only with the quantifier ostatni (Engl.: the last) can the meaning of "the last member of" be met with. Such a usage seems less and less frequent in contemporary Polish.

\footnotetext{
22 http://sjp.pwn.pl/slowniki/autsajder.html. Date of access: 04.04.2016.

23 These terms are falling into obsolescence, though, due to their being definitely politically incorrect.
} 


\title{
3.2.1.3. Meaning shift
}

Amongst the whole collection of less-frequent/rare borrowings, only two cases have been classified as the ones which underwent a shift of meaning, these lexical items are corner and foksal. At first glance the former seems to exemplify the category of words which extended their meaning with the passing of time (it is given in Fisiak in the sense of "cartel type" (1961a: 121)). At present, nonetheless, only its spelling variant - korner - exists in the meaning quoted below, however, mainly as a dictionary entry (in: Stownik Języka Polskiego s.v. korner) ${ }^{24}$ :

\begin{abstract}
A speculative operation in which a combination or syndicate buy up the whole of any stock in the market, or the whole available supply of any commodity, so as to drive speculative sellers into a corner, by rendering them unable to fulfil their engagements except by buying of the combination of corner-men at their own price. Also fig. (Of U.S. origin.) (OED, s.v. corner, n.).
\end{abstract}

Corner has been re-borrowed into Polish amongst such soccer terms as, for instance, golkiper or faul, ${ }^{25}$ and its polonized orthography is also in use alongside the original one, apparently even more commonly.

The latter, foksal, which used to mean "a railway station", "playground located outside of the city", "evening garden party" (Fisiak 1961a; Stownik Języka Polskiego, s.v. foksal ${ }^{26}$ ) and derived from Vauxhall, ${ }^{27}$ survived up until now only as one of Warsaw street names.

\subsubsection{Spelling changes}

The present sub-section does not aim at tracing back changes in orthography of the selected group of borrowings since their earliest days in Polish; rather, it aims at observing what has changed between the orthographic version(s) offered in Fisiak (1961a, 1970) and the one(s) found in either the National Corpus of Polish or the Internet entries dating from the year 2000 onwards (or both). The information given below is by no means definite since one cannot be sure that the orthographic variants provided by Fisiak in his dissertation were the only ones present in Polish over fifty years ago (amongst a variety of issues Fisiak tackled in his work on English borrowings in Polish spelling was not one of them).

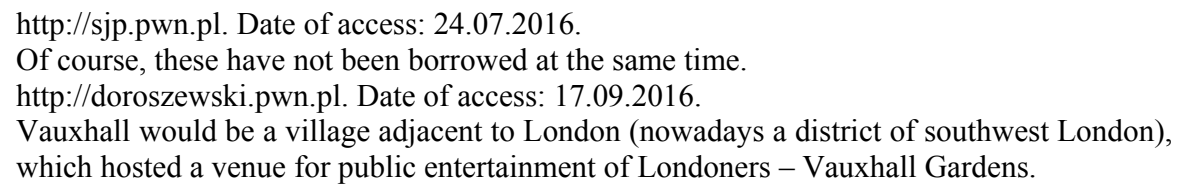


Out of 329 less-popular items, only 44 words (13.37\%) exist nowadays in either variant forms or orthography different from the one noted by Fisiak in his dissertation and his $(1961 \mathrm{~b}, 1970)$ articles based on the same lexical material. Generally, in the case of these 44 borrowings one can talk about two orthographic tendencies, which run counter to one another: the first one is the process where next to a polonized spelling variant provided by Fisiak there is an ostensibly newer one, which conforms to original, English spelling practices (the phenomenon called here "dissimilation"). The other trend manifests itself in polonizing the spellings of words which existed in the Polish language in their original visual form (in other words one talks here about the "assimilation" phenomenon). Before a more detialed discussion of these, two isolated cases warrant our attention.

One of the tokens drawn from Fisiak appears in present-day Polish, although not very frequently, in a hyphenated form, whereas Fisiak (1961a, 1970) gives the form catch as catch can (style of wrestling); the spelling variant with hyphens, catch-as-catch-can, has been recorded in both the National Corpus of Polish as well as on the net. The other isolated case is covercoat, which is currently mostly present in the form of the cover coat.

When it comes to the more productive trends, croswind exhibits the dissimilation tendency mentioned above: initially, this borrowing had undergone partial assimilation which manifested itself in the loss of the double consonant, a phenomenon relatively frequent in assimilated borrowings, cf., e.g., business > biznes (Mańczak-Wohlfeld 1995: 44); however, nowadays it is recorded, especially on the Internet, in its English spelling with $<\mathrm{ss}>$. Similarly, britania (a type of metal alloy) and falstaf (good-for-nothing) can be found on Polish websites in orthographic variants with two homogeneous digraphs: britannia and falstaff respectively.

Some other examples where an orthographically assimilated form yielded to the original one (or its approximation) are, for example, ceter (one of canine breeds). With the passing of time it has given way to seter, the spelling variant which is closer, but not identical to its English original (setter). Yorkshir (Yorkshire swine), in turn, initially lost a word-final letter ${ }^{28}$ only to regain it later on. Fisiak's blajnd (fare evader), although extremely rare in Polish, can be mainly found in the orthographic representation blind. Next, such borrowings assimilated decades ago as sprej (drops of water) and autsider (for example, the last athlete during a race) have also started to appear in their English spellings (spray and outsider). The same tendency is displayed by the following items: bluming - blooming (steel producing technology), fajwoklok - five o'clock, dropszot - drop shot (in Fisiak 1961a: "a relatively soft hit in tennis after which

28 The loss of which is observable in such other examples as kernite > kernit (mineral type). 
the ball lands close to the net"), ${ }^{29}$ rostbef - roast beef, czester - chester (a type of cheese), telerekording - telerecording (process of film-storing television programs), and skajlajt - skylight ("a window in the roof of a house or on a ship's deck"). ${ }^{30}$

The next three words listed in Fisiak's dissertation, namely drajwer (a kind of golf club), boj (as in: cabin boy), and pul (type of cartel) tend to be used in the $21^{\text {st }}$-century Polish in their English versions - driver, boy and pool, respectively. The assimilated variants ${ }^{31}$ seem to be the marginal ones; this may have to do with the fact that these three words have been re-borrowed into the Polish language, however, in meanings different from the original ones.

This process of dissimilation as well as the usage of original ways of spelling of a given borrowing might have been brought about by an increased popularity of English among Poles, their raised language awareness, cultural contact via the modern media (with commercials laden with English brand names), and, last but not least, the phenomenon of re-borrowing of certain lexical items, frequently in a new meaning and also in an original orthographic form.

Conversely, such words provided by Fisiak (1961a) as cheviot (a fabric of cheviot wool), cockpit, ${ }^{32}$ jersey (kind of knit fabric), leader, forcing (a forcing bid in contact bridge), shorthorn (breed of cattle), slice (a type of tennis hit), scrubber (a device used to remove gases from industrial exhaust), tubbing (in Fisiak (1961a: 124): steel hoops), have been assimilated, as a consequence of which one can came across the following variants in Polish: szewiot, kokpit, dżersej, lider, forsing, szorthorn, slajs, skruber, and tubing.

Furthermore, chartyzm (a mid-nineteenth century working-class movement), kok (cook on a ship), katgut ("a tough thin cord made from the treated and stretched intestines of certain animals, especially sheep, and used for stringing musical instruments and tennis rackets and for surgical ligatures"), ${ }^{33}$ sisal (a species of Agave), sprej, and welbot (a kind of fishing/housing facility vessel) acquired additional polonized spellings: czartyzm, kuk, ketgut (the latter appeared alongside the original spelling catgut), sisal, spraj (also: spray), welbat (and walbat).

Finally, the word skrecz mentioned in Section 3.2.1.2. is interesting to look at: in current Polish, or more specifically amidst Polish tennis terminology there exists a variant $k r e c z$, which by some speakers of Polish is regarded as the only

\footnotetext{
Drop shot is also used in Polish to denote one of angling techniques. http://www.merriam-webster.com/dictionary/skylight. Date of access: 20.08.2016. Alongside their respective meanings. In Fisiak's (1961a) understanding kokpit is a space in a yacht from which it is steered, the meaning which is (or used to be) narrow; hence its inclusion in the category of lesscommon borrowings.

33 http://www.thefreedictionary.com/Gut+strings. Date of access: 07.07.2016.
} 
correct form. This semantic split means there is no confusion between krecz in tennis and skrecz as used by DJs, which is apparently derived from scratching in tennis; cf:

Figure 4. Folk etymology of krecz.

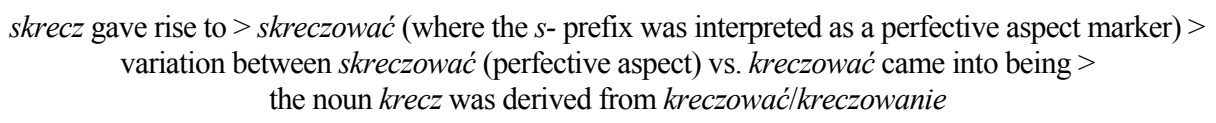

\subsubsection{Technical vocabulary and jargon terms}

Even though jargon is often perceived as tantamount to technical vocabulary, in this section the distinction between these two phenomena is assumed. Thus, the latter embraces mainly borrowings existing in the realms of industry, technology, and architecture (shipping, alloys, metallurgy, mining, railway technology, electricity, vehicles and automotive industry, maritime architecture) as well as scientific (chemistry, biology, geology, dendrology) terms, whereas the former groups borrowing in the realm of literature, sports-specific and fashion/fabric-specific vocabulary, hunting, styles of music and cinematography terms, etc. The common denominator for these two groups is their obscure character, oftentimes not understood by out-group members. Because of space limitation, only (relatively) most numerous categories are briefly discussed below in order to give the reader a gist of what these items are like.

Out of the corpus of less-common/uncommon terms consisting of 329 entries, there are as many as $248(=75.4 \%)^{34}$ which have been classified as either technical or jargon terms (see Appendix 2 for breakdown numbers). The rest of borrowed entries $(59=18 \%)$ are put together in the category which warrants a brief explanation: it is a "bag" containing, on the one hand, such hard-to-shelve borrowings as dizet ("a hard black semi-precious form of lignite, able to receive a brilliant polish and used ornamentally, esp. in Victorian mourning jewellery" (the OED, s.v. jet n.)), John Bull (a stereotypical Englishman), peri (a fairy) and, on the other, words which would be popular to a greater or lesser extent back in the day and which are nowadays either rare, uncommon or they (substantially) broadened their meanings: boks (in Fisiak 1961a: 113: a separate stall for a horse in a stable), kombajner (a reaping machine, a harvester), nylony (nylon stockings), ${ }^{35}$ rajd (in Fisiak 1970: aggressive foray by the military), and waterklozet (water

34 Results rounded off to the first decimal place.

35 Although at present this piece of garment is undergoing revival of a kind. 
closet). ${ }^{36}$ Yale (Fisiak 1970: yale-lock) ${ }^{37}$ has also been categorized here due to its not fitting into the classification presented in Appendix 2. Interestingly, in the current Polish usage Yale does not exist as a common noun, but rather as a brand name, usually in collocations or with various substantives: kłódka Yale (Engl.: Yale padlock), sejf Yale (Engl.: Yale safe) or zamek typu Yale (Engl.: Yale-type lock), etc.

Coming back to technical terms per se, it is the category comprising shipping/sailing words which prevails numerically in Fisiak's corpus. In fact, as many as 48 items constitute terminology of specific nautical/maritime character; these are, for instance, azdyk (Engl.: asdic = "an echo-sounding device for the detection of submarines"), ${ }^{38}$ ket (Engl.: cat boat = "a kind of sailing-boat having the mast placed very forward and rigged with one sail"), ${ }^{39}$ pakajs (Engl.: pack ice $=$ "an expanse of sea ice formed from pieces of ice driven together into a mass that covers all or most of the sea surface, as found in polar seas"), ${ }^{40}$ rumb (Engl.: rhumb = "the line or course followed by a ship or other vessel sailing in a fixed direction"), ${ }^{41}$ and topsel (Engl.: topsail = "a sail set above the lower course, orig. the uppermost sail"). ${ }^{42}$

Technical terms ${ }^{43}$ sensu stricto which are to aid technical communication are best represented by the following items: bluming (Engl.: blooming machine, blooming mill = "the reducing of cast- or pig-iron into 'blooms" $),{ }^{44}$ rewerser (Engl.: reverser $=$ "a mechanism or control used to reverse the direction of operation or motion of an engine or vehicle; esp. (a) a mechanism in a steam engine for controlling the point in the piston stroke at which steam is admitted to the cylinder and thereby the direction of motion; ... (b) a switch which changes the connections of electric traction motors for this purpose"), ${ }^{45}$ rototrol (Engl.: rototrol regulator, rototrol generator $=$ a rotating amplifier with either two or three stages of amplification) or selsyn ("a kind of electric motor closely resembling a magslip and employed similarly in pairs in order esp. to transmit

36 The truncated form klozet is still used in Polish, but its etymon is very rare.

37 "A proprietary name for locks and keys, used esp. to denote a lock with a cylindrical barrel that can be turned only when a key with a specially serrated edge is inserted so as to displace a number of pins by the correct distances (invented by Linus Yale) (the $O E D$, s.v. Yale, n.2)

38 The $O E D$, s.v. asdic.

39 The $O E D$, s.v. cat boat.

40 The $O E D$, s.v. pack, n.1.

41 The $O E D$, s.v. rhumb.

42 The OED, s.v. topsail.

43 Interestingly, Fisiak (1961a) includes here a case of indirect borrowing, namely fletner (which also exists as flettner; Engl.: flettner servo tab); it is a noun derived from the name of its inventor of German provenance, Anton Flettner.

44 The $O E D$, s.v. blooming, n.2.

45 The $O E D$, s.v. reverser. 
and receive information about the position or motion of mechanical equipment"). ${ }^{46}$

When it comes to jargon terms, the corpus contains a number of specialized sports lexical items. These are, for instance, bek (Engl.: back = "one of the players stationed behind the 'forwards,' e.g. 'half-back,' 'three-quarter back'; the duty of the simple 'back' is to defend the goal"), ${ }^{47}$ groggy (in Fisiak: dizzy after a boxing fight), skiff ("a long narrow racing-boat for one oarsman, outrigged, usually fitted with a sliding-seat, and covered in fore and aft with canvas"), ${ }^{48}$ spurt ("to put on increased speed, to make greater exertions, for a short time"), ${ }^{49}$ stayer ("a person or animal who has great powers of endurance"), ${ }^{50}$ and strok (Engl.: pulling stroke = "the oarsman who sits nearest to the stern of the boat, and whose "stroke' sets the time for the other rowers"). ${ }^{51}$

Borrowings existing in the realm of literature are lakista (lake poet) and eufuizm (Engl.: Euphysm = a Baroque literary movement).

Summing up, due to the specialized character of these borrowings and, what stems from it, the relative rarity of their usage, they have, as indicated earlier, neither undergone (drastic) semantic changes nor orthographic alterations since 1961. Obsolete or archaic character of other words transferred to Polish is described in the section to follow.

3.2.4. Historic political/social vocabulary, obsolescent terms, and outdated phenomena

The present sub-section deals with historic political/social terms and currently obsolete borrowings. The former amount to 22 items $(=6.6 \%)$; the latter ${ }^{52}$ have been classified as outdated during the process of checking the presence of Fisiak's borrowings in the National Corpus of Polish as well as in the Google search engine. Thus, a given borrowing extracted from Fisiak (1961a) has been classified as obsolete if it did not occur in the NCP, Google hits were mainly confined to on-line dictionary entries/crossword solvers, and the $O E D^{53}$ marked a given word (or its meaning) as archaic/outdated and/or illustrated it by means of examples confined to decades prior to the end of the twentieth century.

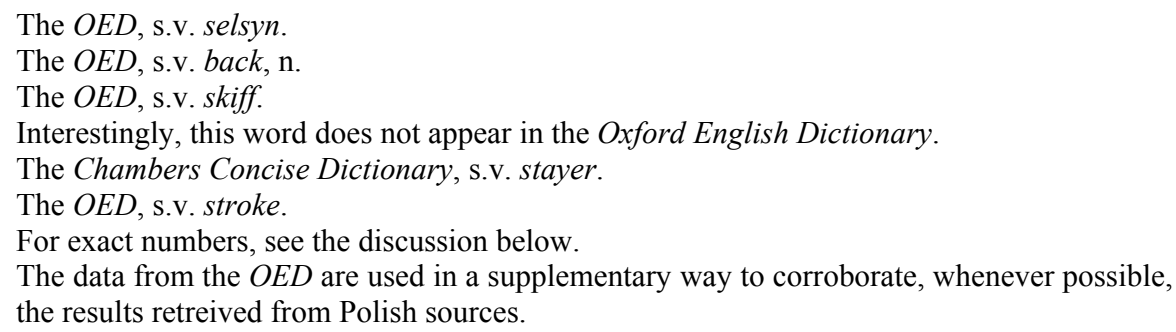


Focusing briefly on (historic) political terms which can be found in Fisiak's corpus: nowadays these are characterized by obscurity and not infrequently do they have to be accompanied by a word of explanation (cf. Example 4 below depicting denizacja (Engl.: denization)).

4. Ludność kolonii dzieliła się na:

Posiadających obywatelstwo (angielskie bądź nabyte w koloniach $-\mathrm{z}$ ograniczeniami dla katolików)

Posiadających ograniczone prawa obywatelskie, bez praw politycznych, nadane przez króla (denizacja). ${ }^{54}$

[English]: The population of the colony was divided into: The ones possessing citizenship (either English or acquired in the colonies with restrictions for Catholics)

The ones with limited civil rights, without political rights, granted by the king (denization).

Some other "outdated" political/social borrowings which designate either defunct or obsolete processes/phenomena are: badenpowelizm (the BadenPowell scouting traditions and intentions), dizyngoizm (Engl.: jingoism "the feelings and beliefs of people who think that their country is always right and who are in favor of aggressive acts against other countries"), ${ }^{55}$ home-rule ("government of a place (such as a country or territory) by the people who live there instead of by another country"), ${ }^{56}$ pul (Engl.: pool = "an arrangement between parties (esp. who were previously competing) to fix prices or rates, eliminate competition, etc.; a cartel"), ${ }^{57}$ and $s c a b$ ("a person who refuses to join a strike or who takes over the work of a striker" $).{ }^{58}$

As for obsolescent terms, essentially, out of the entire corpus of 329 English borrowings in Polish, $47(=14.3 \%)$ have been classified as obsolescent, excluding the group of such historical political/social terms as the ones mentioned above as well as borrowings which have been classified as "historic architecture" (e.g., kromlech). ${ }^{59}$ This group comprises words which lost their relevance or became defunct; these are borrowings denoting phenomena which fell into oblivion due to technological advances and cultural changes (or both). In order to illustrate this category, let us use the following examples: brek

\footnotetext{
54 https://notatek.pl/stany-zjednoczone-ameryki; Date of access: 07.05.2016.

55 The Meriam-Webster Dictionary, s.v. jingoism; Fisiak (1961a: 65) claims it is an English counterpart of chauvinism.

56 The Merriam-Webster Dictionary, s.v. home-rule.

57 The $O E D$, s.v. pool.

58 The $O E D$, s.v. $s c a b, \mathrm{n}$

59 The Merriam-Webster Dictionary, s.v. cromlech, n.
} 
(Engl.: break = "a large wagonette" ${ }^{60}$ became a thing of the past; by the same token, lawenda (Engl.: lavender; cinematography = lavender-colored film) must have been already bygone in the 1970s, as the following quote from the Oxford English Dictionary suggests:

1973 D. A. SPENCER Focal Dict. Photogr. Technol. 340 Lavender, fine grain motion picture film used for making duplicate black and white negatives and coated on lavender tinted base to minimise halation and prevent confusion with ordinary positive stocks. Modern duplicating stock is on a grey tinted base and differs sufficiently in appearance from ordinary positive that the lavender tint is not necessary. ${ }^{61}$

Similarly, biograf (Engl.: biograph = "an early form of motion-picture camera and projector combined") is defined by the Oxford English Dictionary (s.v. biograph) as historical; even though denizacja (Engl.: denization = "an act of becoming a denizen") is defined by the OED (s.v. denization) with brevity, denizen, in turn, is defined more thoroughly as "a person who dwells within a country, as opposed to foreigners who dwell outside its limits. (In this, the original sense, including and mainly consisting of citizens)" and the dictionary annotates this entry as "now rare" and appearing in literary style. Fisiak's donkeyman ("a man in charge of ... a donkey-engine", where the latter is "a small steam-engine, usually for subsidiary operations on board ship, as feeding the boilers of the propelling engines, etc." $)^{62}$ is illustrated by the Oxford English Dictionary (s.v. donkeyman) only by a nineteenth-century quotation. The Corpus of Historical American English ${ }^{63}$ provides only a handful of quotes of both hyphenated (donkey-man) and solid word variants (donkeyman) from the end of the nineteenth and beginning of the twentieth centuries. In a similar vein, sweating-system was mainly used in the course of the nineteenth century, as suggested by both $O E D$ quotes and the $C O H A$ attestations. The next borrowing - halifaxy (Engl.: Halifax skates = types of ice-skates with curved blade fronts whose name comes from the Canadian city of Halifax) - exists nowadays mainly as a (online) dictionary entry, or can be recorded on websites devoted to crossword clues and answers. Incidental attestations appear in the National Corpus of Polish, however, in a historical context, as illustrated by the quote below:

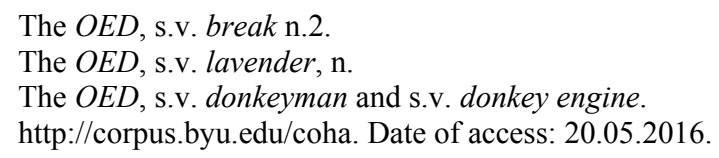


5. Współczesne łyżwiarstwo zaczyna się jednak dopiero w połowie XIX w.; prekursorem jest baletmistrz Jackson Haines ze Stanów Zjednoczonych. W Europie powstają pierwsze publiczne lodowiska. Ślizgają się wyższe sfery. Panowie we frakach, melonikach, na łyżwach halifaksach, całych ze stali lub żelaza, albo na dżeksach - na stałe przyśrubowanych do butów. ${ }^{64}$

[Engl.: Modern skating begins, however, in the mid-nineteenth century; its precursor is a ballet master, Jackson Haines from the United States. The first public skating rinks are built in Europe. It is the upper classes which skate. Gentlemen skate in tails, bowler hats, on halifax skates - made of steel or iron - or on Jackson figure skates ${ }^{65}$ permanently bolted to their shoes.]

With technological progress in (tele)communication, juz (the printing telegraph) - noun derived from the name of the inventor, David Edward Hughes - has naturally fallen into disuse. Next, rels (Engl.: rails) is described in Fisiak (1961a) as outdated, which is corroborated by information provided by Doroszewski's (1958-1969) ${ }^{66}$ dictionary (s.v. rels, n.).

Other vocabulary items which fall into the category of outdated terms/phenomena are, inter alia, grum; its English equivalent, groom, denotes a "man of inferior position; a serving-man; a man-servant; a male attendant" (the $O E D$ s.v. groom, n.). This meaning is marked in this dictionary as obsolete and archaic. Gundek (Engl.: gun-deck = "a deck which carries guns; esp. in an oldfashioned ship of the line, the lowest of the decks on which guns are placed") ${ }^{67}$; luizyt (Engl.: lewisite $=$ "colorless or brown vesicant liquid ... developed as a poison gas for war use") ${ }^{68}$ and lyddit (Engl.: lyddite = "a high explosive composed chiefly of picric acid") ${ }^{69}$ are military terms/weaponry which ceased to be synthesized due to their being replaced by more advanced chemical compounds. Kompaund (Eng.: compound = a compound locomotive") is illustrated by the $O E D$ solely by nineteenth-century examples. The word pudlingowanie (Engl.: puddling) carrying the meaning of an old-time technology “... of converting pig iron into wrought iron or rarely steel by subjecting it to heat and frequent stirring in a furnace in the presence of oxidizing substances" (Merriam-Webster Dictionary, s.v. puddling, v.) fell out

64 “Bo życie kręci się wokół tafli” Polityka no. 2437. Date of publication: 31.01.2014; Date of access: 13.02.2016.

65 This is an outdated common name for a type of figure ice skates.

66 http://sjp.pwn.pl/doroszewski, s.v. rels,

67 The $O E D$, s.v. gun-deck.

68 The Merriam Webster Dictionary, s.v. lewisite, $\mathrm{n}$.

69 The Merriam Webster Dictionary, s.v. lyddite, $\mathrm{n}$. 
of use because this metallurgic process was displaced by the more modern and simultaneously effective ones. Welbot (alongside its spelling variants welbat and walbat; Engl.: whaleboat) is marked in Polish Wikipedia as a historic term. ${ }^{70}$

Finally, Fisiak (1961a: 14) provides the reader with the word falstaf bearing the denotation of a witty good-for-nothing, which is also a rarity on the 'Polish Internet'; as a matter of fact, this word of English origin can be mainly found in online dictionaries, dictionaries of terms of foreign origin, and websites providing crossword puzzle answers. Since there are more borrowings which nowadays require explanation due to their being very uncommon, they warrant a separate sub-section.

On a side note, interestingly, the popularity of certain borrowings in Polish seemingly coincides with their usage in English (similarly to the case of pin-up girl mentioned earlier). Let us take, for instance, the previously mentioned selsyn. Google n-grams (cf. Figure 4) illustrate the peak of its usage in English books; more specifically, they graphically depict the phenomenon of its gradual obsolescence since the 1950s and the peak evidently overlaps with Fisiak's data collection process. ${ }^{71}$

Figure 4. Selsyn in Google n-grams.

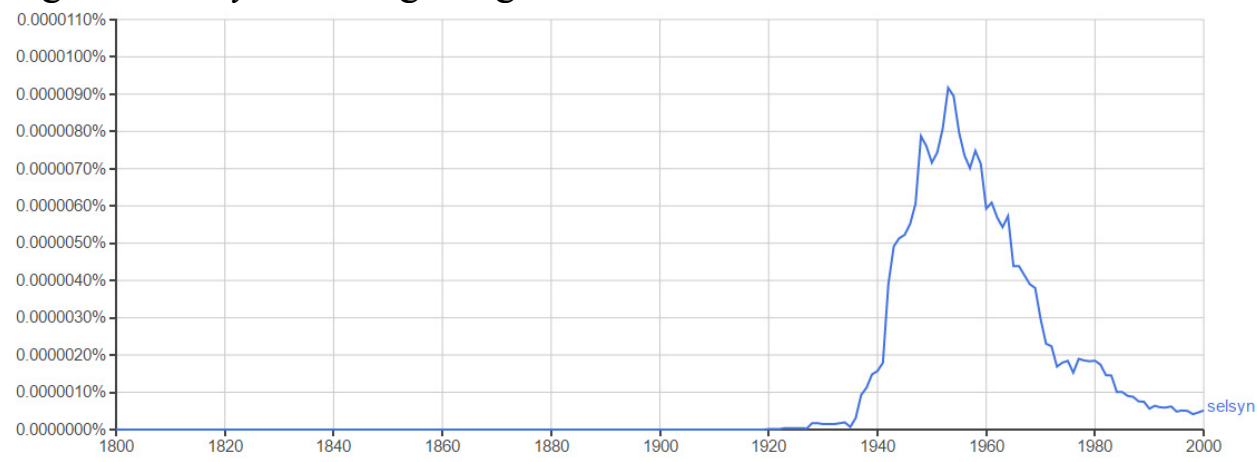

70 https://pl.wikipedia.org. s.v. welbot. Date of access: 11.04.2016.

71 This transformer was first used in the early 1900s in the control system of the Panama Canal. It witnessed wider use during the World War II - to control the position of heavy guns. Later on, it was used in naval warships as well as passenger ships and its smaller variant found its application in motion picture equipment (https://en.wikipedia.org/wiki/Synchro; date of access: 03.09.2016). As the Polish Wikipedia claims, this transformer stopped being used due to its being substituted by cheaper electronic devices (https://pl.wikipedia.org/wiki/Selsyn; date of access: 03.09.2016). The $O E D$ (s.v. selsyn, n.) gives the last quote from the 1960s. All these (as well as Figure 4) might testify to selsyn's more intensive use between 1940s and 1980s. 


\subsection{Lexical items which warrant explanation}

This final section of the paper provides selected examples of borrowings which, due to their being far from commonplace, require explanation or a word of clarification. It basically comprises lexical items of English provenance which due to their rarity - at first glance seem "peculiar", which means that speakers of Polish might have problems with comprehending their semantics. Their present-day status might indicate their not getting soaked up into Polish and they are rather infrequently used, as indicated earlier, but for certain specific contexts. Such cases are, among other ones, catch as catch can, rumb (Engl.: rhumb), strok (Engl.: stroke), sandwich-man, or traveller's check. Even though all these can sometimes be recorded on Polish websites, they are usually accompanied by Polish explanation or their usage might be confined to scribble websites/sites for crossword puzzle lovers (see Examples 6-10 below).

6. Catch wrestling (znany również jako „catch-as-catch-can” co thumaczyć można jako „wszystkie chwyty dozwolone”) był jedynym rodzajem zapasów w czasie Igrzysk Olimpijskich w Saint Louis w 1904 roku. $^{72}$

[English:] Catch wrestling (also known as "catch-as-catch-can" which can be explained as "no holds barred") was the only type of wrestling during the 1904 Olympic Games in St. Louis.

7. Marynarze mierzą katy w rumbach. ${ }^{73}$

[English:] Sailors measure angles in rhumb lines.

8. STROK - zawodnik siedzący za sternikiem i nadający tempo osadzie; ${ }^{74}$

[English:] The stroke - a rower seated behind a cox and setting the pace of the rowing team.

9. $\quad$ Przez następne dni chodził po ulicach miasta $\mathrm{z}$ planszami na plecach $\mathrm{i}$ piersi jak żywy słup ogłoszeniowy, sandwich man. ${ }^{75}$

[English:] For the next couple of days he was walking the city streets wearing pieces of cardboard on his back and chest like a living advertising column, sandwich man.

\footnotetext{
http://www.grapplerinfo.pl/wszystkie-chwyty-dozwolone/. Date of access: 20.08.2016. http://zadane.pl/zadanie/335922. Date of access: 13.07.206.

https://trudneslowa.wordpress.com/tag/sport/. Date of access: 13.07.206. This website attempts to illuminate difficult words existing in Polish, words which "you might not be aware of".

75 http://rodzina.swiatkobiety.pl/psychologia/news-czy-powinnismy-wybaczac-klamstwozdrade-i-,grzech, nId 1506223. Date of access 05.09.2016.
} 
10. Jednak skupowane są tylko ściśle określone czeki, m.in. podróżne (traveller's cheque) ... ${ }^{76}$

[English:] However, only well-defined checks are bought, including traveler's checks ...

\section{Conclusions}

Professor Jacek Fisiak's input in the field of English words transferred to Polish remains unquestionable. His study from the mid-twentieth century did lay foundations for a number of future studies on the lexical/semantic influence of the English language on Polish. Items listed in his 1961 dissertation and 1970 article alongside their accompanying meanings can be found in articles and dictionaries which were published decades later (e.g., Mańczak-Wohlfeld 1987, 1994, 1995, 2010).

When it comes to the status of Fisiak's borrowings in 2016, all lexical items listed in his doctoral dissertation are still present in Polish to a greater or lesser extent. More specifically, over $50 \%$ of cases have gotten so much assimilated within the past half a century and are in such a common use that their English provenance has generally faded into obscurity. The other ones, usually jargon and/or technical terms, are not in everyday repertoire of Poles for obvious reasons; these, in turn, can be found either in dictionaries or websites with specialized content/the ones whose aim is to provide crossword puzzle solutions (or in all these sources).

Such less-common lexical items which have been the primary focus of the present paper have undergone two types of changes: semantic and orthographic; as expounded earlier, the notion of semantic change in this context seems somewhat elusive since the majority of words categorized here under the name "extension" are actually the ones re-borrowed to Polish, but with a new denotation, different from the one provided by Fisiak (1961a, 1970). As for spelling change, not a very substantial fraction of less-popular words has undergone orthographic alterations, which comes as no surprise in the light of uncommonness/rarity of words which fall into the category being of the primary interest in the present study. All in all, Figure 5 given below offers a synopsis of quantitative and qualitative analyses carried out on the basis of Fisiak's 1961 corpus, with borrowed lexical items grouped alongside the changes they have undergone as well as sub-types into which they can be categorized:

$76 \mathrm{http} / /$ www.pracaizycie.pl/artykuly/finanse-analizy-opinie/karteczka-platnicza/. Date of access: 17.03.2016. 
Figure 5. A precis of quantitative analysis performed on Fisiak's 1961 corpus.

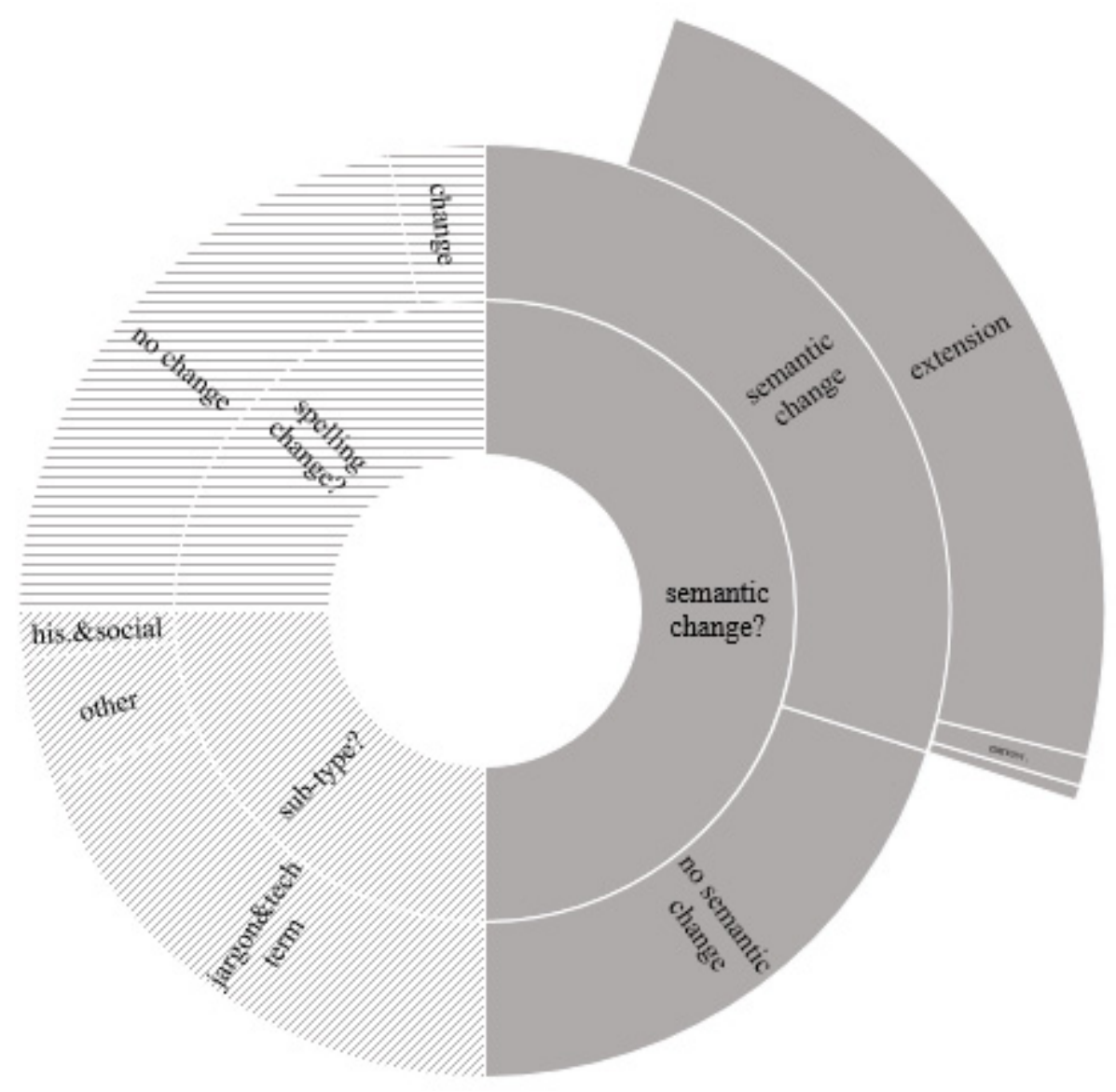


Appendix 1

Semantic categories accompanied by exemplary words and their respective meanings. ${ }^{77}$

\begin{tabular}{|c|c|c|}
\hline category: & exemplary word & meaning \\
\hline $\begin{array}{l}\text { alloys/metallurgy/ } \\
\text { mining }\end{array}$ & brytania & $\begin{array}{l}\text { [Engl.: Britannia] An alloy consisting chiefly } \\
\text { of tin, antimony, and copper, resembling silver } \\
\text { in appearance and formerly much used for } \\
\text { cheap tableware. }\end{array}$ \\
\hline $\begin{array}{l}\text { animal } \\
\text { breeds/breeding }\end{array}$ & leghorn & $\begin{array}{l}\text { Designating a lightweight breed of domestic } \\
\text { fowl that originated in Tuscany, noted as a } \\
\text { prolific layer of large white eggs; designating a } \\
\text { bird of this breed. }\end{array}$ \\
\hline $\begin{array}{l}\text { automobile } \\
\text { (industry) }\end{array}$ & bufor & $\begin{array}{l}\text { [Engl.: buffer] A mechanical apparatus for } \\
\text { deadening the force of a concussion. }\end{array}$ \\
\hline aviation & runway & $\begin{array}{l}\text { A specially prepared surface at an airfield or } \\
\text { airport, along which aircraft take off and land. }\end{array}$ \\
\hline biology & mimikry & $\begin{array}{l}\text { [Engl.: mimicry] The close external } \\
\text { resemblance of an animal or plant (or part of } \\
\text { one) to another, or to an inanimate object; a } \\
\text { similar resemblance between parts or features. }\end{array}$ \\
\hline botany & rajgras & $\begin{array}{l}\text { [Engl.: rye grass] Any of several tufted grasses } \\
\text { of the genus Lolium, esp. L. perenne and } L \text {. } \\
\text { multiflorum, extensively cultivated as fodder } \\
\text { and pasture grasses, and also commonly used } \\
\text { for lawns. Also with distinguishing word. }\end{array}$ \\
\hline chemistry/physics & bakelit & $\begin{array}{l}\text { [Engl.: bakelite] A proprietary term for a } \\
\text { condensation product of phenol or other } \\
\text { phenolic bodies and formaldehyde used as a } \\
\text { plastic and for insulating purposes. Also attrib. }\end{array}$ \\
\hline cinematography & postsynchron & $\begin{array}{l}\text { [Engl.: post-synchronizing] the process } \\
\text { involving adding (a sound recording) to film or } \\
\text { video footage after shooting and so as to } \\
\text { synchronize with its images. }\end{array}$ \\
\hline clothing & dizemper & $\begin{array}{l}\text { [Engl.: jumper] A kind of loose outer jacket or } \\
\text { shirt reaching to the hips, made of canvas, } \\
\text { serge, coarse linen, etc. }\end{array}$ \\
\hline
\end{tabular}

77 Fisiak (1961a and 1970) gives rather scant definitions of the borrowings he discussed; thus the definitions provided in Appendix 1 have been taken from the Oxford English Dictionary online (date of access: 07.03.2016 and 10.09.2016). 


$\begin{array}{lc}\text { dendrology } & \text { hikory } \\ \text { dying substances } & \text { lac-dye } \\ \text { economy/pecuniary } & \text { konsole } \\ \text { words } & \\ \text { electricity (circuits) } & \text { feeder } \\ & \\ \text { equine } & \\ & \\ \text { fabric } & \text { tatersal } \\ \text { geology/geography } & \text { pedyment }\end{array}$

historic architecture kromlech

(obsolete) political $\quad s c a b$ terms

hunting master
[Engl.: hickory] A North American tree of the genus Carya ...

a scarlet dye prepared in India from lac.

[Engl:: consols] An abbreviation of Consolidated Annuities, i.e. the government securities of Great Britain.

(a) A heavy untapped main for carrying electrical energy to a distribution point or system. (b) A branch-wire to supply a house, etc.; (also) an electrical connection between an aerial and a transmitter or receiver of electromagnetic waves.

[Engl.: Tattersall] The horse-auction market established by Tattersall in 1766 at Hyde Park Corner. Also transf. and fig.

[Engl.: cheviot] A cloth made from Cheviot wool.

[Engl.: pediment] A broad, gently sloping, eroded rock surface that extends outwards from the abrupt foot of a mountain in arid and semiarid regions and is usually slightly concave and partly or wholly covered with a thin layer of alluvium.

[Engl.: cromlech] A structure of prehistoric age consisting of a large flat or flattish unhewn stone resting horizontally on three or more stones set upright; found in various parts of the British Isles, esp.in Wales, Devonshire, Cornwall, and Ireland. Also applied to similar structures in other parts of the world.

A workman who refuses to join an organized movement on behalf of his trade; in extended uses: a person who refuses to join a strike or who takes over the work of a striker; a blackleg; a strike-breaker. orig. U.S.

In the title of a person who owns or controls a pack of hounds, esp. the member of a hunt who is designated to supervise the kennels and

78 Even though Fisiak (1970: 44) classifies it as not belonging to the category of equestrian events, but amongst trade terms. 
legal issues

literature

machinery

maritime

architecture/marine

technology

measures and

weights

medicine

military

music (styles) alderman

lakista

angledozer

brekwater

buszel

parkinsonism

hunting arrangements, as master of beagles, master of buckhounds, master of foxhounds, master of harriers, etc., or with the designation of a particular pack of hounds. Also simply as master (when the role may be understood from the context). Occas. in extended use.

A civil officer in a borough, city, etc., next in dignity to a mayor; a senior member of the legislature of a municipal council or corporation; (in some countries) a member of the legislature of a city, borough, or ward; a city councillor; (Brit.) the chief officer of a ward in the City of London (a member of the Court of Aldermen and of the City of London Corporation).

[Engl.: lake poet].

[Engl.: angle dozer] A type of bulldozer with a blade which is or can be set at an oblique angle, so that earth is pushed to one side rather than in the direction of travel.

[Engl.: breakwater] Anything that breaks the force of the waves at a particular place, esp. a solid structure of rubble and masonry erected to form or protect a harbour, etc.

[Engl.: bushel] A measure of capacity used for corn, fruit, etc., containing four pecks or eight gallons.

[Engl.: parkinsonism] A syndrome resembling Parkinson's disease but associated with other diseases of the central nervous system, exposure to certain toxins, or the use of certain drugs. Also (more fully idiopathic parkinsonism): Parkinson's disease itself.

More fully Sten gun: a type of light, rapid-fire, sub-machine-gun.

A development of jazz, begun in the U.S. at the end of the 1939-45 war, characterized by complex harmony, dissonant chords and highly syncopated rhythm. 


\begin{tabular}{|c|c|c|}
\hline $\begin{array}{l}\text { railway } \\
\text { (technology) }\end{array}$ & rels & $\begin{array}{l}\text { [Engl.: rails] steel bars that provide the running } \\
\text { surfaces for the wheels of locomotives and } \\
\text { railroad cars. }\end{array}$ \\
\hline sailing/shipping & trymowanie & $\begin{array}{l}\text { [Engl.: trimming] the fitting out, repairing, or } \\
\text { cleaning the bottom of a ship. }\end{array}$ \\
\hline sport & $\begin{array}{l}\text { catch as catch } \\
\text { can }\end{array}$ & the Lancashire style of wrestling. \\
\hline substances & portland-cement & $\begin{array}{l}\text { a hydraulic cement manufactured from } \\
\text { limestone and clay or sand, commonly used in } \\
\text { concrete and resembling Portland stone in } \\
\text { colour. }\end{array}$ \\
\hline technology & juz & $\begin{array}{l}\text { Noun coined from the name of the inventor, the } \\
\text { printing telegraph. }\end{array}$ \\
\hline vehicles & tilbury & $\begin{array}{l}\text { A light open two-wheeled carriage, fashionable } \\
\text { in the first half of the 19th c. }\end{array}$ \\
\hline other & waterclozet & $\begin{array}{l}\text { [Engl.: water closet] Now chiefly arch., hist., } \\
\text { or euphem., except in the abbreviated } \\
\text { form W.C. a toilet. }\end{array}$ \\
\hline
\end{tabular}


Appendix 2

Categorized jargon terms amongst the less-frequent borrowings

\begin{tabular}{lc}
\hline Category & No of items \\
\hline sailing/shipping & 48 \\
sport & 44 \\
(obsolete) political terms & 22 \\
cinematography & 14 \\
fabric & 13 \\
alloys/metallurgy/mining & 12 \\
economy/pecuniary terms & 12 \\
machinery & 12 \\
railway (technology) & 10 \\
clothing & 8 \\
military/weaponry & 8 \\
technology & 8 \\
geology/geography & 7 \\
chemistry/physics & 5 \\
electricity (circuits) & 5 \\
animal breeds/breeding & 4 \\
botany & 4 \\
maritime architecture/ technology & 4 \\
vehicles & 4 \\
automobile (industry) & 3 \\
biology & 3 \\
music (styles) & 270 \\
aviation & 2 \\
hunting & 2 \\
legal issues & 2 \\
literature & 2 \\
measures and weights & 2 \\
medicine & 1 \\
dendrology & 1 \\
dying substances & 1 \\
equine & 2 \\
historic architecture & 2 \\
substances & 2 \\
total & 2 \\
\hline & 2 \\
\hline
\end{tabular}




\section{REFERENCES}

Brocki, Zygmunt \& Jan T. Hołowiński. 1956. Uwagi o stownictwie handlu morskiego (na marginesie pracy $W$. Skibickiego 'Angielsko-polska terminologia handlu morskiego'). Gdańsk: Zakł. im. Ossolińskich we Wrocławiu.

The Chambers Dictionary. http://www.chambers.co.uk/dictionaries/the-chambers-dictionary.php.

Fisiak, Jacek. 1961a. Zapożyczenia angielskie w języku polskim: Analiza interferencji leksykalnej. Łódź: Unpublished Ph.D. dissertation, Uniwersytet Łódzki.

Fisiak, Jacek. 1961b. Zjawisko depluralizacji niektórych rzeczowników angielskich zapożyczonych przez język polski. Język Polski 2. 138-139.

Fisiak, Jacek. 1970. The semantics of English loanwords in Polish. Studia Anglica Posnaniensia 2. 41-49.

Karłowicz, Jan, Adam Kryński \& Władysław Niedźwiedzki. 1900-1927. Słownik języka polskiego. Warszawa: Nakładem prenumeratorów i Kasy im. Mianowskiego.

Lam, Stanisław. 1939. Encyklopedyczny stownik wyrazów obcych: Pochodzenie wyrazów, wymowa, objaśnienia pojęć, skróty, przystowia, cytaty. Warszawa: Księgarnia i Dom Wydawniczy Trzaska, Evert i Michalski.

Linde, Samuel Bogumił. 1854-1859. Stownik języka polskiego. Lwów: Drukarnia im. Ossolińskich.

Mańczak-Wohlfeld, Elżbieta. 1987. Najstarsze zapożyczenia angielskie w polszczyźnie. Język Polski 67. 25-31.

Mańczak-Wohlfeld, Elżbieta. 1994. Angielskie elementy leksykalne w języku polskim. Kraków: Universitas.

Mańczak-Wohlfeld, Elżbieta. 1995. Tendencje rozwojowe współczesnych zapożyczeń angielskich w języku polskim. Kraków: Universitas.

Mańczak-Wohlfeld, Elżbieta (ed.). 2010. Słownik zapożyczeń angielskich w polszczyźnie. Warszawa: Wydawnictwo Naukowe PWN.

The Merriam-Webster: Dictionary and thesaurus. http://www.merriam-webster.com.

National Corpus of Polish. http://www.nkjp.uni.lodz.pl.

The Oxford English Dictionary, 3rd edition (online). http://www.oed.com.

Pęzik, Piotr. 2012. Wyszukiwarka PELCRA dla danych NKJP. In Mirosław Bańko, Rafał L. Górski, Barbara Lewandowska-Tomaszczyk. Marek Łaziński, Piotr Pęzik \& Adam Przepiórkowski (eds.), Narodowy Korpus Języka Polskiego, 253-279. Warszawa: Wydawnictwo PWN.

Rysiewicz, Zygmunt. 1954. Stownik wyrazów obcych. Warszawa: PIW.

Skibicki, Wacław. 1951. Stownik angielsko-polski handlu morskiego. Warszawa: Polskie Wydawnictwa Gospodarcze.

Stowniczek morski, Z przedmowa dr. A. Brucknera. 1935. Toruń: Kasa im. Mianowskiego.

Śląski, Bolesław. 1937. O terminologię morska (w odpowiedzi P. Z. Jasińskiemu $-z$ powodu nowego przektadu Conrada-Korzeniowskiego). Kępno: Published by the author.

Wieczorkiewicz, Bronisław. 1939. Słownik wyrazów obcych. Warszawa: Wydawnictwo J. Przeworskiego. 